\title{
How to Teach English to Immigrant Children: Canadian PedagogicalTheory and Practice, 1910-1960
}

\author{
R.D. Gidney and W.P.J. Millar
}

\section{ABSTRACT}

The idea of Anglo-conformity and the attack on immigrant cultures in the early twentieth century is a well-documented theme in Canadian social history. It involved both languagelearning and acculturation. But there has been a curious lack of attention to just how children were to be taught the language and implicitly the culture of the dominant society. This article addresses both the pedagogical theories that were developed to ensure that immigrant children learned English, and the implications for the implementation of language-learning programs.

\section{RÉSUMÉ}

Dans l'histoire sociale canadienne, l'anglo-conformisme et les offensives lancées contre la culture des immigrés au début du vingtième siècle est un thème bien documenté qui implique à la fois l'apprentissage de la langue et l'acculturation. Curieusement, peu d'études se sont intéressées à la manière dont les enfants s'initiaient à l'anglais et par voie de conséquence assimilaient la culture de la société d'accueil. Cet article s'intéresse à la fois aux théories pédagogiques développées pour s'assurer que les enfants d'immigrants apprenaient l'anglais ainsi qu’aux conséquence de la mise en place des programmes de langue.

"Teach the children to speak, to read and to write English," declared a Saskatchewan school inspector in 1913; "this is our first and great educational commandment." Such views, with all their implications, were commonly held in early-twentieth-century Canada, and they have become a familiar part of the pertinent historiography as well. ${ }^{2}$ Particularly (though not exclusively) in the West, the assimilation of great numbers of non-English-speaking children into Anglo-Canadian culture was one of the highest priorities of politicians, educational policy-makers, and the public alike. To that end, the school was thought to be central to teaching both the English language and Anglo-Canadian values. But just how was that to be done? What pedagogical theory underpinned instruction in the English language in the half-century or so before the 1960s? What classroom arrangements existed to implement it? How 
well were teachers trained to do the job and how successful were they? In this article we propose to address these questions. ${ }^{3}$

In 1914 Alberta's Department of Education issued its first authoritative guide for the "Teaching of English in Non-English Speaking Schools." 4 The pedagogical method it adopted was known as the "direct" or "natural" method of language learning. This was a technique that abjured the use of the child's mother tongue in the classroom on the principle that a beginner learned English by speaking English, much in the same way as children learned their first language - by listening to and imitating those around them. While the term was not used at the time, we would now label the direct method, "language learning by immersion."

The Alberta guide made no compromises about the use of an intermediary language: from the moment a non-English child arrived at school, instruction was to be exclusively in English. Two years later, in 1916, the Ontario Department of Education published a manual for Teaching English to French-speaking Pupils. It too advocated the "direct" method, though it was somewhat less unbending about the use of the mother tongue:

One of the most important features of the Direct Method is the avoidance of any unnecessary use of the mother tongue in acquiring another language. Some have claimed that the pupil's mother-tongue should be absolutely excluded. Most, however, of those who have had serious experience with young children believe that complete avoidance of the mother-tongue is not advisable...Hence it should be used occasionally to avoid great loss of time, to give important explanations, and to test the pupils' comprehension of a difficult idea. Experience has proved that the best success has been attained by those who, while trying to reduce the use of the mother-tongue to a minimum, do not set it aside altogether. ${ }^{5}$

The direct method was not something new in language learning theory: it was well known in both Europe and North America and had already found a commercial application in the "Berlitz method." ${ }^{6}$ But in the second decade of the twentieth century it had a particular resonance for Canadian educators. Confronted with the large numbers of children who spoke no English when they began school, they seized upon it as an effective means of teaching English without the use of the mother tongue and without resorting to bilingual schooling. That is to say, it provided a pedagogical justification for the larger political project of assimilating immigrant children into Anglo-Canadian norms. ${ }^{7}$

The best Canadian exposition of the case for the direct method (and, emphatically, against bilingualism in education) was provided by Norman F. Black, at the time a Saskatchewan high school teacher and inspector, in his book, English for the Non-English, published in $1913 .{ }^{8}$ By means of a questionnaire, Black canvassed the opinions of over 150 individuals, including senior department of education officials and inspectors across the country, a large number of Canadian teachers, and experienced administrators and practitioners in the United States, Britain, South 
Africa, and Australia. ${ }^{9}$ Altogether, the book is a remarkable catalogue of contemporary views about how best to teach English as a second language to primary schoolchildren.

Black's first key question was this: how rapidly could beginners learn English? His respondents were near-unanimous: given a qualified teacher, proper methods, and regular attendance on the part of the pupil, non-English children could, within a few months or a year or two, master enough of the language to enable them to cope with the regular elementary school curriculum. ${ }^{10}$ But what constituted "proper methods"? Here Black posed his second and third questions: should the teacher use the language of the home to initiate children into English? And should languages other than English be taught, or used to teach parts of the curriculum, contemporaneously with English-language learning? ${ }^{11}$

He began by reviewing a Nova Scotia commission of 1902 that had recommended that Acadian pupils be taught initially in both French and English, that teachers in such schools be bilingual, and that the transition to English-only instruction should begin in the fifth year of school. Black noted that this had subsequently become policy in Nova Scotia; while many people elsewhere were sympathetic to such arrangements, he added, "Nova Scotia stands practically alone in America in officially mandating the doctrine that progress in the learning of English requires the teacher's knowledge and use of the vernacular" (by which he meant any non-English language of the home). ${ }^{12}$

Black found that 60 per cent of his respondents thought it "advantageous" (though not necessarily essential) for teachers to have some familiarity with the vernacular. He agreed that this could be helpful. But requiring it posed two insuperable practical problems. First, it was nearly impossible to find enough bilingual teachers who also possessed "other and more important qualifications"; and, at the same time, it shut out "the great majority of adequately trained teachers otherwise available." 13 For evidence he turned to Ontario's Merchant Report - the study of that province's FrenchEnglish schools, published a year earlier in 1912. Merchant had found that about 80 per cent of the teachers in such schools held either "no semblance of legal qualifications or else [held] certificates lower than Second Class" - and large numbers in either category could not speak, let alone teach, the English language properly. ${ }^{14}$ This was the situation, Black pointed out, in communities where a single vernacular prevailed. "If schools such as these must be surrendered to ignorance and incompetence, what about those hundreds of schoolrooms in which the non-English speaking beginners represent not one single nationality but from three or four to a dozen or fourteen? If the teachers of these classes must be possessed of a familiarity with the vernacular languages of their pupils there is nothing for it but to close up such schools and give up the problem in despair."15

Thus, while it might be "advantageous" for a teacher to have some familiarity with the vernacular, Black asked, was it essential? Forty per cent of his respondents thought it entirely unnecessary in instructing beginners. Indeed, even the "ill-starred" Nova Scotia report had virtually conceded the point by recommending "the Berlitz System of teaching English. As everyone familiar with language teaching is of course 
well aware," he added, "an outstanding characteristic of this method is insistence upon the exclusive use of the language that is being taught." 16 To Black, the views of his respondents seemed conclusive: "Great numbers of teachers in all parts of the English speaking world find it quite practicable to give their pupils, in a year or less, such a knowledge of English as would enable them henceforth to receive effective instruction through the medium of English alone and to progress as rapidly in general education as do children of English parentage." 17

Black then turned to his third question: Should any formal instruction in the vernacular be carried on in the schools? ${ }^{18}$ Here he found that opinion was sharply divided across the English-speaking world: there were those who favoured teaching in two languages and those who did not. Black did not favour any absolute exclusion of the vernacular but he firmly believed that English must take precedence in the early grades: instruction in another language could begin later if so desired. To prove his point he returned to the findings of the Merchant Report. Most children, he reminded readers, left school at 12 or 13. In Ontario's bilingual schools, children began learning in French, and most subjects, other than English, were being taught in French. The result was that large numbers of these children were leaving school with a wholly inadequate command of English. Merchant had offered a variety of remedies for this situation, but he remained wedded to the idea that there should be a gradual transition from mainly French to mainly English instruction - a transition that would take four or five years. If, Black remarked bluntly, Merchant had looked to experienced opinion in the Canadian West as well as that expressed by most American experts, he would have realized that such delays in acquiring English were not only unnecessary but unconscionable. The bilingual schools of Ontario, he declared,

steadily tend to cease to be bi-lingual, unless the use of English as the language of instruction be imperatively demanded as a condition for the payment of school grants. In the presence of such a situation, Dr. Merchant's approval of the use of the vernacular, as the chief teaching medium for the first five years of the child's school life, is little less than calamitous...Ontario's experience should be a warning to all other parts of the English-speaking world. ${ }^{19}$

How then were teachers to introduce English to non-English pupils? For Black, that was to be done by making English the exclusive language of the classroom. Words would initially be taught by linking them to things or actions. Oral expression would be fostered by example, by imitating sentence formation, by oral drills for the use of nouns, verbs, prepositions, etc., by developing stories around such things as catalogue illustrations and picture books, by free conversation and dramatizations. Reading and writing would proceed in somewhat similar fashion, from simple to complex, from concrete to more abstract. ${ }^{20}$

The application of the theory, it is perhaps worth adding, extended beyond the classroom. In his description of the methods of an idealized teacher in the nonEnglish school, Black had this to say: 
"My playground is the most important part of my school, for the teaching of English," says Miss Robinson. "I find that it is a great mistake to be too busy to join the children at recess. In a few days I shall have taught them a number of jolly, noisy games, introducing all the English terms I can. Experience has taught me, like many others, that that is the very best place to encourage the habitual use of the new language out of school. In a month, or perhaps less, we shall speak almost nothing else during the recess of Mondays, Wednesdays and Fridays... Before the end of the term we shall extend the use of English at recess to Tuesdays and Thursdays. I carefully prepare for special games by teaching action words, such as run, jump, hide, hunt, strike, pat, clap, drop, sit, stand, etc., and introduce games involving such actions, which we of course talk about in English. Often I ask the children to explain the games they are playing. I take note of grammatical errors and of unknown but necessary words, and afterwards use the games as a basis for language lessons in school. All this helps to introduce the habitual use of English. ${ }^{21}$

This emphasis on the value of games and the playground as a teaching tool was conventional in the literature, as were other school-related activities such as the creation of a school garden or the school fair, where the use of English went hand in hand with the teaching of skills and values. ${ }^{22}$

Black had many other points to make along the way, including recommendations for improved teacher training and other departmental policies. But the essence of the argument was this: children must begin learning English upon entering school; there was an effective way to do it; the best techniques avoided the use of the vernacular in the classroom; and instruction in another language, if offered at all, must only begin after the child knew enough English to meet the demands of the elementary curriculum.

Black's book was not a singular influence in the methodology of language learning. We doubt, for example, that it was paramount in shaping Alberta's policies - the Alberta guide, after all, was published no more than a year after Black's book, and the direct method was already familiar to Albertan and other Canadian officials and academics early in the century. W.J. Sisler, a Winnipeg teacher and school principal and one of the pioneers in Manitoba's attack on the problem of teaching English to nonEnglish children, was advocating the direct method as early as 1906 . A few years after Black, Anderson's much more influential book gave the direct method a full chapter, with no acknowledgement to Black at all. ${ }^{23}$ But we have devoted considerable attention to Black because he directs attention to views and practices already widespread in educational circles, and illustrates the kind of evidentiary base, and the kind of reasoning, that was making the direct method the method of choice for teaching immigrant children during the second decade of the twentieth century.

Until about the 1960s, in any case, the direct method went unchallenged, at least among those administrators and practitioners responsible for the education of immigrant children. In the sources we have consulted, there is no evidence of debate over methods or even a canvass of alternatives; rather the reverse: the justification for 
the direct method was not at issue and the articles are mainly about how to apply it effectively. ${ }^{24}$

Still, one has to ask, how widely and how well was theory translated into practice? These are difficult questions to answer not only because the evidence is so thin but also because the issues are complex. Immigrant communities, after all, were never monolithic, and different groups reacted in different ways. Some children thrived under even the most trying of circumstances because they liked school or were simply good at it, because parents put a high value on schooling for cultural or economic reasons, or believed, for whatever reasons, that learning English was essential to a child's best interests in a new country. For an equally wide range of reasons, other children did not. ${ }^{25}$ There is nothing unusual about this: the success or failure of pedagogical theories or methods is notoriously influenced by the matrix of attitudes and circumstances children bring to school. Similarly, teachers' abilities, experience, specialized training, as well as their prejudices and temperaments have to be taken into account.

By the time Black was doing his research, some large American cities had already established segregated classes for children who spoke no English: using the direct method, such immersion programs aimed to prepare them as quickly as possible to enter regular classrooms. ${ }^{26}$ Some Canadian cities were doing the same. Neil Sutherland notes that, before 1920 at least, "in Winnipeg, where there was a large and highly concentrated immigrant population, schools placed children who came to them with no knowledge of English into special classes where all work was 'subservient to instruction in English.' As soon as the child learned the language, he was transferred to the 'grade suited to his general education and stage of development.' Toronto followed the same practice." ${ }^{27}$ Calgary, on the other hand, never attempted such classes until after World War II. ${ }^{28}$ And even where special classes had been established before 1920, they may have persisted only so long as large numbers of immigrant children were entering urban school systems. Winnipeg, for example, apparently abandoned special classes for non-English pupils during the interwar years; this may have happened in Toronto as well. ${ }^{29}$ Whether or not urban boards did or did not maintain these sorts of special classes probably depended on the size and resources of the board, and the size and concentration of its immigrant population. There was also less demand for them in the 1930s and the war years, when immigration to Canada virtually dried up. And large urban boards with sophisticated special education facilities may have dealt with non-English children on an individual basis within their special education programs - by the 1930 s and ' 40 s the Winnipeg School Board, for example, evidently employed that approach. ${ }^{30}$

When immigration resumed after World War II and more financial resources were available to both local and provincial authorities, special classes for the non-English reappear in the record. In some cases these were set up specifically to deal with a sudden and temporary influx of particular groups of immigrants. Calgary, for example, set up special classes for an influx of immigrant students in 1950 but apparently did not maintain such classes. ${ }^{31}$ In the late 1950 s, Calgary's elementary school teachers complained to Alberta's Royal Commission on Education about the problems this created for them. 
New Canadians are usually assigned to classes according to their age. The teacher has insufficient time to teach an adequate course in English to these children. However, if these children are not given definite teaching time they develop poor work habits and poor attitudes. In large schools the influx often results in every room teacher duplicating the teaching of vocabulary and primary reading.

\section{Recommendations}

Establishment of special classes of stated periods for the teaching of written and spoken English to New Canadians. These children could be socialized with children of their own age group in a regular classroom. Special classes would allow them to associate with other children experiencing language difficulties. ${ }^{32}$

In other cases, as in Winnipeg for example, special classes became integral parts of the school program. ${ }^{33}$ But one way or another, references to, or reports on, special classes for non-English children became more frequent during the $1950 \mathrm{~s} .{ }^{34}$ Different boards, however, might deal with the problem in quite different ways. An article in 1956 in the Canadian School Journal provides a good example. In Toronto, Kent Public School had an organized half-time program; in Niagara Falls, placement was much more ad hoc, including placing English beginners in "opportunity classes" that were mainly intended for slow learners. ${ }^{35}$

What happened to non-English-speaking children in smaller communities, and especially in the one-room schools of rural Canada? Where immigrant groups were specifically targeted by provincial authorities, their children were probably exposed to teachers trained and/or experienced in immersion techniques. ${ }^{36}$ But other than that, rural children were mostly put in regular primary classrooms and left to sink or swim. Their success or failure in acquiring the English language probably depended on their numbers in proportion to the rest of the class, and the enterprise of the teacher, whose ethnic background may have mattered too. During the interwar years an increasing number of young people with non-anglo backgrounds entered normal schools in the western provinces. In 1930, for example, at the Regina Normal School, 30 per cent of the students were of non-anglo origin; at Moose Jaw Normal School in 1929, the figure was 39 per cent. ${ }^{37}$ Another study concluded that "for the years 1927-8 to 1935-6 inclusive," 24 per cent of Manitoba's Normal School students were of non-"Anglo-Saxon" or non-"French" background. ${ }^{38}$ An Alberta analysis in 1943 of the ethnic origins of students at the Edmonton Normal School found that 30 per cent were of non-British origin in 1930-31; by the late 1930s and early 1940s the figure was hovering around 50 per cent. ${ }^{39}$ It is plausible to think that, based on their own experience, these teachers might have had some know-how and sympathy for their non-English-speaking students.

However, the evidence we have been able to locate, though thin and consisting mainly of reminiscences, suggests the difficulties of teaching and learning the English language in most non-urban schools. One teacher in rural Alberta at mid-century, for example, found herself with "one little boy [who] could hardly speak a word of English. He was in grade two but hadn't finished his grade one lessons yet. [I] spent 
extra time with him on both his English and his lessons and brought him a long way in that year." ${ }^{\circ 0}$ Another teacher recalled, "This was a community in which there were many Ukrainian and Polish people, so language differences caused some difficulty. The beginners knew no English, some of the others very little, and English was my only language. However, with the help of a grade eight girl we were able to communicate, and it was surprising how quickly they learned." ${ }^{41}$

Late in life, Ethel Workman would remember her first job this way: "I graduated from Saskatoon Normal School in 1929 and my first school was a brand new one. 13 miles from Battleford called Winding River...I had 7 beginners, only one of whom could speak English. What a beginning for a beginning teacher. The other 6 knew only Ukrainian or French. I'm afraid the other grades were neglected while I taught Grade I English." ${ }^{2}$

Yet another prairie teacher described her experience as follows: "There were fifty-one children in grade one. The people, I soon discovered, were all Eastern European-Ukrainian, Russian, Romanian and Galician...Language was the real and worst problem...It had never dawned on me that there were places in Alberta where English was not spoken. From grade three up English was spoken, but the beginners were my Waterloo. I did not know how to handle the situation.”33

In an article based on interviews with teachers who taught in the Okanagan valley in the 1920s, Penelope Stephenson writes as follows:

[There were]...not only...schools where class size made them difficult to organize but also, and in many instances simultaneously...those where the pupil population included children from various ethnic backgrounds. Many teachers also had to accommodate children, often newly arrived in Canada, who spoke little or no English... the vast majority of rural teachers were not professionally equipped to deal with the difficulties of language and cultural change. In the 1920s, English as a Second Language (ESL) training for teachers, as well as the necessary curriculum materials, were undeveloped and certainly unavailable in rural schools...The specific practices and strategies that rural teachers actually employed to effectively instruct non-English-speaking pupils were thus, of necessity, essentially pragmatic ones. When Ellison School opened in September 1927, [it] ... had to accommodate a group of eighteen Austrian children, whose parents had recently moved into the district to work on the tobacco farms... [the teacher explained] "[They] didn't speak a word of English ...couldn't understand a thing I said...I was completely stunned"... the only way that [the teacher] could communicate his instructions was by way of "waving my hands around and making signals and signs etc!"’4

Either implicitly or explicitly, one thing several of these passages point to is that teachers received little preparation for teaching non-English-speaking children during their initial Normal School training. We cannot be sure this is the case because what actually goes on in classrooms is not necessarily indicated by lists of required courses or brief descriptions of course content. ${ }^{45}$ But certainly, those who commented 
on the matter assumed teachers were unprepared. Black, writing in 1913, noted that "the probability is that the teacher will never have received any adequate instruction bearing upon the teaching of English to children who have never used it."46 Similarly Anderson a few years later: "The writer strongly urges that a special course be instituted in the provincial normal schools of the Western Provinces looking to the preparation of teachers for the work of teaching in non-English communities." ${ }^{47}$ Commenting on his experience as an inspector in the Vegreville district of Alberta in the mid-1920s, Milton LaZerte remarked that "teachers are not professionally equipped for the teaching of a foreign language, in this case the 'foreign' language being English." 48 Faced in the 1930s with a large group of non-English pupils, one new prairie teacher would later comment that "my Normal School training hadn't given me much help in trying to teach non-English speakers to speak English." ${ }^{49}$

We have found only a single reference to ESL as a required part of the ordinary Normal School program: in 1939-40 the Winnipeg Normal School included, in a course entitled "Teaching Reading," a modest component (one topic out of eleven in a weekly three-hour course) devoted to "Teaching reading to non-English children." ${ }^{50}$ Distinct ESL courses do not appear to have been required as part of initial teacher training. For example, they were not part of the regular program in Alberta's Normal Schools in the 1920s, 1930s, or 1940s. ${ }^{51}$ Nor, after the University of Alberta took over elementary teacher training from the Normal Schools, were such courses offered until the mid-1960s. Even at that point they were optional rather than a part of the regular program that all students would be exposed to. ${ }^{52}$

Occasionally, voluntary courses were available. In 1921, Alberta's Edmonton and Camrose Normal Schools offered a month-long course during the regular school year for teachers "wishing to" work or "at work in schools amongst New Canadians." 53 Summer school sessions were attended by large numbers of teachers in order to upgrade certificates or obtain training in specialized areas. But there are few references to specialized training in ESL in the course listings; such courses appear only sporadically. For example, in 1929 and 1930 British Columbia offered a summer course that was clearly ESL-related, as well as another in 1933; however, other listings in the decade of the 1930 s do not include such courses. ${ }^{54}$ Manitoba offered ESL summer courses each year between 1916 and 1921. No such courses are listed for the Manitoba summer school for 1923 or 1924, or in its calendars for 1925 through to $1942 .{ }^{55}$ The singular exception was 1928: that year, in a well-advertised course conducted by Manitoba's leading authority on the subject, W.J. Sisler, seven students enrolled in it out of a total summer school enrolment of $751 .{ }^{56}$ Alberta did not offer ESL courses at its summer school in the teens but in 1920 "for the first time" offered "Education in Non-English Communities II" and also listed two other courses: "English for non-English" and "Education of non-English I." Twenty students chose to take those courses out of a total enrolment of $376 .{ }^{57}$ But for most years after that no similar course was offered. ${ }^{58} \mathrm{~A}$ tabulation of all summer courses taught across Canada in 1931 contains not a single ESL course. ${ }^{59}$ And Ontario's Department of Education didn't offer one until $1958 .^{60}$

For much of the latter half of the twentieth century, the University of British 
Columbia's Mary Ashworth was the doyenne of Canadian academics teaching and writing about ESL and, more generally, a wide variety of initiatives relating to multicultural issues. Prior to World War II, she writes, the education of New Canadians was governed by three assumptions: "that the role of the school was to assimilate these children; that bilingual education was not a good method of educating these children;...[and] that anyone who spoke English could teach English as a second language." ${ }^{1}$

Change began to occur in the 1950s and gained momentum in the 1960s and 1970s. A rapid growth in the number of non-English children, especially in the largest urban areas, but equally, a major shift in the climate of opinion which emphasized the virtues of diversity and multiculturalism, and more sophisticated research into language learning, led to a considerable expansion in ESL programs and increased specialist training in second-language learning. ${ }^{62}$ However, various problems remained. In the 1960s, training in ESL techniques was initially offered in Ontario and then also at the University of British Columbia, but there was difficulty in finding experts to teach ESL, and most of the teachers taking the courses were interested in adult programs, not in public school education. Moreover, few school boards were interested in hiring trained ESL teachers. Indeed, in Ashworth's opinion, some boards relegated ESL classes to those teachers unable to cope with regular classes, which meant that "for those children who had the misfortune to be taught by an incompetent rather than a trained ESL teacher the year spent in the ESL class was a waste of time." ${ }^{63}$

Thus, while some progress was being made in the 1960s and early 1970s, when Ashworth conducted a survey for another of her books, she found that, as late as the early 1970s, 56 per cent of those who had been teaching New Canadians for three years or less were wholly untrained for the job. ${ }^{64}$ She would later comment:

As many regular classroom teachers will, at some time, teach students for whom English is a second language, it would seem advisable that they should at least be introduced to some basic concepts during their preservice training. This, however, is not the case. Few teachers entering the profession receive sufficient information on second language teaching to help them help their students.

It was, she continued, over seventy years since Black had called for proper training for ESL teachers. Yet even now "the majority of regular teachers, most of whom will meet ESL students in their classes from time to time, have little or no background in second language acquisition theories or in methods of teaching ESL through the regular curriculum." 65

In sum, one critical job of Canadian schools across the first half of the century was defined as the assimilation of immigrant children into the language and values of the majoritarian culture. Making English the exclusive or near-exclusive language of the classroom was regarded widely, by educators, politicians, and others, as a fundamental part of that strategy. During the second decade of the century the "direct method" came to dominate educational theory about teaching English to the non-English. 
That method was not only advocated in the Canadian literature but was the method authorized by provincial educational authorities. A corollary of the method was that the language of the home was to be excluded from the classroom and the playground. Except in special circumstances, however, teachers were not trained in how to teach English to non-English children; as a consequence, in most schools - above all in the rural schools, which until mid-century constituted the majority of classrooms - teachers and pupils were left to sink or swim in an ad hoc way. It was only in the later twentieth century, with the new emphases on multiculturalism and the value of diversity, that the efficacy and use of the direct method, along with the assimilative goals that underpinned it, began to be challenged. ${ }^{66}$

\section{Notes}

1 Quoted in Marilyn Barber, "Canadianization through the Schools of the Prairie Provinces before World War I: The Attitudes and Aims of the English-Speaking Majority," in Ethnic Canadians: Culture and Education, ed. Martin L. Kovacs (Regina: Canadian Plains Research Center, 1978), 283. For a similar statement, see J.T.M. Anderson, The Education of the New Canadian: A Treatise on Canada's Greatest Educational Problem (Toronto: Dent, 1918), 24-25 (note the sub-title). The phrase "Canada's greatest [educational] problem" was in common use-see Norman F. Black, "Western Canada's Greatest Problem: The Transformation of Aliens into Citizens," Western School Journal [WS] 5 (May 1914): 95.

2 For some key sources on the drive for Anglo-conformity, see for example Neil Sutherland, Children in English-Canadian Society: Framing the Twentieth-Century Consensus (Toronto: University of Toronto Press, 1976), 203ff. and esp. 209-15; Marcella Derkatz, "Ukrainian Language Education in Manitoba Public Schools: Reflections on a Centenary," in Issues in the History of Education in Manitoba: From the Construction of the Common School to the Politics of Voice, ed. Rosa Bruno-Jofré (Lewiston/Queenston: Edwin Mellon Press, 1993), 173-74 [citing inspectors' reports for Manitoba schools, 1906-15]; Keith A. McLeod, "Education and the Assimilation of the New Canadians in the North-West Territories and Saskatchewan, 1885-1934" (PhD diss., University of Toronto, 1975), 258-62; Manfred Prokop, "Canadianization of Immigrant Children: Role of the Rural Elementary School in Alberta, 1900-1930," Alberta History 37, 2 (Spring 1989):1-10; Timothy J. Stanley, Contesting White Supremacy: School Segregation, Anti-Racism, and the Making of Chinese Canadians (Vancouver: UBC Press, 2011), esp. chap 4; Rosa Bruno-Jofré, "Schooling and the Struggles to Develop a Common Polity, 1919-1971," in Papers in Contemporary Issues in Educational Policy and Administration in Canada: A Foundations Perspective, ed. Rosa Bruno-Jofré and Lois Grieger (Winnipeg: University of Manitoba, 1996), 78-79. On Toronto, see Luigi G. Pennacchio, "Toronto's Public Schools and the Assimilation of Foreign Students, 1900-1920," Journal of Educational Thought 20, 1 (April 1986): passim; Robert F. Harney and Harold Troper, Immigrants: A Portrait of the Urban Experience, 1890-1930 (Toronto: Van Nostrand Reinhold, 1975), chap. 4. For an extended version of Anderson's core arguments, see Douglas A. Lawr and Robert D. Gidney, eds., Educating Canadians: A Documentary History of Public Education, updated 2nd ed. (Toronto: Van Nostrand Reinhold, 1978), 133-37.

It should be noted that in the territories it was assumed until well after mid-century that English would be the language of instruction in schools. See for example Norman John Macpherson, Dreams and Visions: Education in the Northwest Territories from Early 
Days to 1984 (Yellowknife: Department of Education, Government of the Northwest Territories, 1991), 107, 115-16; Heather E. McGregor, Inuit Education and Schools in the Eastern Arctic (Vancouver: UBC Press, 2010), 73-74.

3 Throughout the article, we will often use the term "ESL" (English as a Second Language). It's an anachronism but is useful just because of its familiarity.

4 Alberta, Department of Education, Public School Manuals, Primary Work for Grades I and II (1914), 121-34, "Teaching of English in Non-English Speaking Schools." This provides a detailed explanation of how to go about teaching ESL using the direct method. While it is a good introduction to the subject, see also the very clear exposition of the direct method written two decades later by Phillip Sheffield, an experienced teacher and school inspector in British Columbia, in The SchoolXVIII, 8 (April 1930): 666-70; XVIII, 9 (May 1930): 775-80.

5 Ontario Department of Education, Manual on Teaching English to French-Speaking Pupils (Toronto: King's Printer, 1916), 6.

6 On this point see J.W. Eaton, "The Direct Method in the Teaching of Modern Languages," Queen's Quarterly XX (April 1913): 447-60; Norman F. Black, English for the Non-English (Regina: Regina Book Shop, 1913), esp. chap. IX, "Bibliography," where Black cites and annotates the extant books and articles on the subject. See also Susan Bayley, "The Direct Method and modern language teaching in England, 1880 1918," History of Education 27, 1 (1998): 39-57.

7 This is not mere conjecture on our part. Anderson, for example, explicitly links the two at p. 133, Education of the New Canadian. Generally on assimilation as a political project, see Bill Maciejko, "Ukrainians and Prairie School Reform, 1896-1921: Ethnic and Domestic Ideologies in Modern State Formation," Canadian Ethnic Studies XXII, 2 (1990): passim.

8 The book originated as a doctoral dissertation at the University of Toronto, probably completed the same year. For his career see McLeod, "Education and Assimilation," 147 and 292.

9 The list of those consulted is on pp. 6-13 of Black, English for the Non-English.

10 This is the topic of Black's chap. II.

11 These two questions are central to the book's longest chapter, chap. III, "The Place of the Child's Mother Tongue in the School."

12 Black, English for the Non-English, 49-50.

13 Ibid., 51.

14 Ibid., 52. The author was F.W. Merchant, a senior official in the Ontario department of education; the formal title was Report on the Condition of English-French Schools in the Province of Ontario.

15 Ibid., 53.

16 Ibid., 59.

17 Ibid., 49. Italics added.

18 His discussion of this issue begins at ibid., 61.

19 Ibid., 77.

20 See ibid., chap. VI, "Methods and Devices for the Teaching of English." Black presents this chapter in the form of a model teacher confronting a class exclusively made up of non-English pupils. It is a useful exposition but contains little not explained more fully in the references in note 4 . For yet another description of the method, see Anderson, Education of the New Canadian, $123 \mathrm{ff}$.

21 Black, English for the Non-English, 111-12.

22 See Anderson, Education of the New Canadian, 129-30 (value of games), 134-35 (school concerts), and chap. XIV (school fairs); Alberta, Public School Manuals... "Teaching of English," 122-23 (playground games), 131-32 (school gardens); Prokop, "Canadianization of Immigrant Children," 7-8; English as the language of the 
playground, WSJ I, 3 (March 1906): 5; ibid., XII, 10 (Dec. 1917): 406; The Manitoba Teacher, Nov. 1927, 16; ibid., Oct. 1928, 24. See also the description of in-school and out-of-school methods used by one teacher [Robert England] in his school in a Ukrainian settlement in Saskatchewan, in Bill Waiser, Saskatchewan: A New History (Calgary: Fifth House, 2005), 246-47.

23 WSJI, 3 (March 1906): 4-6; similarly J.T.M. Anderson as early as 1912: see McLeod, "Education and Assimilation," 309, and more generally 304-12. For other examples see the quotations and citations in Prokop, "Canadianization of Immigrant Children," 4. The quotations, identified in his notes 16 and 17, are from 1906 and 1909. Black's book received a favourable review in the WSJVIII, 6 (June 1913): 213-14, and it may have helped popularize the direct method in Manitoba, but given Sisler's local leadership and the number of non-English children that Manitoban teachers had to deal with, it is equally plausible to think that they were already familiar with the method. Three articles written shortly after Black's book was published, in any case, make no reference to his book. See WSJ IX, 7 (Sept. 1914): 173-77; IX, 8 (Oct. 1914): 20913; X, 7 (Sept. 1915): 247. C.B. Sissons does a rather nice job of setting Black within the larger Canadian debate over methodology. See his Bi-lingual Schools in Canada (London: Dent, 1917), 199-212.

24 Our research on this point includes, among other things, reading, across the period, the following journals: the ATA Magazine [ATAM], The School, The Journal of Education for Nova Scotia, The Canadian School Journal, the Western School Journal [Manitoba; title changes to Manitoba School Journal, and The Manitoba Teacher. Though not a complete canvass of the educational press, we think it is representative of different parts of the country, and different types of journals. From this we conclude that the debate over the choice of method was largely closed after 1920. In 1929, Robert England, who had a good deal of experience in these matters, commented, "The Direct Method...is recognized by teachers all over the world as the most effective method...": The Central European Immigrant in Canada (Toronto: Macmillan, 1929), 128. The two Sheffield articles in note 4, published in 1930, take it for granted that the direct method calls for no justification (see particularly p. 666 of the first article). Similarly see ATAMX, 2 (Oct. 1929): 21-22; XXI, 3 (Nov. 1940): 17-20; 29, 4 (Dec. 1948): 11-12. There are frequent references to the issue in the two Manitoba journals, but again, all of them assume (or advocate) the direct method as the preferred methodology. Along with the references in note 23, see, for example, WSJXII, 1 (Jan. 1917): 13-15; XVI, 1 (Jan. 1921): 484-87; XIX, 7 (Sept. 1924): 46-49; XXIII, 1 (Jan. 1928): 15-19; The Manitoba Teacher, Jan. 1928, 17-19, and Nov. 1939, 9. See also Peter Sandiford, ed., Comparative Education: Studies of the Educational Systems of Six Modern Nations (London: J.M. Dent and Sons, 1918), 378-79. The thesis by T.R. McKenzie, "The Past and Present Status of the Teaching of English to Non-English-Speaking Immigrants to Canada, with Special Reference to Ontario" (DEd diss., University of Toronto, 1954), confirms this as well. Though the thesis is exclusively concerned with the education of adult immigrants, his discussion of appropriate methodology, as late as 1954, makes it clear that direct methods and the exclusion of the mother tongue were the accepted norms for secondlanguage teaching throughout the first half of the century. And Vandra L. Maseman suggests it was still the case, in Toronto at least, well into the 1960s. See Maseman, "Multicultural Programs in Toronto Schools," in Cultural Diversity and Canadian Education: Issues and Innovations, ed. John R. Mallea and Jonathan C. Young (Ottawa: Carleton University Press, 1984), 353.

For evidence of some early dissent, see WSJ IX, 5 (May 1914): 77; XII, 8 (Oct. 1917): 306-7; XIV, 1 (Jan. 1919): 14. The ideal solution proposed by one person, probably a teacher, was to hire teachers with the background and language of the community who were also English-speaking, fully qualified, and appreciative of British Canadian culture 
and values - no doubt a far too utopian ideal under the circumstances. See WSJXII, 10 (Dec. 1917): 412-13. While the direct method seems to have been the preferred method across Canada, the exclusion of the mother tongue was not. As in Nova Scotia, its use continued to be approved (within limits) in Ontario's French schools. However we have found no evidence that, before the 1960s, this kind of bilingual approach was advocated for immigrant children.

25 See Sutherland, Children, 206-7. See also the quotation from Peter Stevens in Mary Ashworth, Blessed with Bilingual Brains: Education of Immigrant Children With English as a Second Language (Vancouver: UBC, Faculty of Education, Pacific Educational Press, 1988), 153.

26 Black refers to these American precedents in various places throughout his book. See for example English for the Non-English, 50, 95, 168.

27 Sutherland, Children, 210.

28 Calgary, like most urban boards, experimented with night classes for New Canadians, but these were for adults. We have read through the Calgary School Board minutes and have found no evidence of the creation of special classes for non-English children before 1950. That is also the conclusion of John Mark Taplin, "A Study of Educational Policy Towards Immigrants in Alberta, with emphasis upon English as a Second Language of Instruction and the Indo-Chinese Refugee Movement" (MA thesis, University of Calgary, 1987), 106ff. Similarly, see British Columbia, AR 1945-46, Report of Vancouver Superintendent of Schools, MM79, a night school "for English for New Canadians" which was most likely for older children and/or adults.

29 The Reports of the Winnipeg schools, published annually in the Manitoba Department of Education Annual Reports [hereafter $A R s$ ], routinely list the variety of special classes in the city's system but there are no references to day classes for non-English children from 1920 to 1950. For Toronto, see Royal Commission on Bilingualism and Biculturalism, Book IV, The Cultural Contribution of Other Ethnic Groups, 106, paragraph 288; Maseman, "Multicultural Programs in Toronto Schools," 352-53.

30 See for example the report of the treatment of children with "speech" defects (in special speech education programs) including "dialectical difficulties (principally with pupils of foreign origin)" in Winnipeg Public School Board, AR 1940, 11; ibid., AR 1942, 21. See also the general description of Winnipeg's special education programs in, for example, Report of the Superintendent of Winnipeg Schools in Manitoba, AR 192425, 69: special classes for "pupils handicapped by language difficulties" extend beyond problems learning English but may have included them; ibid., AR 1945-46, 66-67, the work of "adjustment teachers." For an example of how teachers outside large urban systems absorbed the lesson of incorporating ESL into a speech education program, see Libby E. Marek, Donald School, Narol, "Experiment with a Speech Training Program for Elementary Schools," Manitoba School Journal III, 5 (Jan. 1941): 6, 15: "During the last session at the Manitoba Summer School I became aware of the need for good speech standards....Most of my pupils are of Ukrainian parentage and speak only Ukrainian at home. When my pupils start school they know very little English and in most cases no English at all....My solution to the problem was to make use of a speech training programme made available to teachers by the Department of Education" (p. 6).

31 See Taplin, "Educational Policy Towards Immigrants in Alberta," 110-11. On the special classes established by the Vancouver School Board in 1957 for Hungarian refugees, see Helen Raptis, "A Tale of Two Women: Edith Lucas, Mary Ashworth, and the Changing Nature of Educational Policy in British Columbia, 1927-1977," Historical Studies in Education 17, 2 (Fall 2005): 303.

32 Public Archives of Alberta [PAA], 79.350, Royal Commission on Education [Cameron Report], Box 2, Brief to the Royal Commission...Submitted by the Teachers of the Elementary Schools of Calgary, Division 1 and Division 11, sub-locals, Calgary City, Local No. 38, ATA, April 1958, 14-15. 
33 See Winnipeg Public School Board, $A R$ 1953, 4, and 8 (statistics back to 1950); $A R$ 1954, 5; $A R$ 1955, 6; AR 1957, 7; AR 1958, 18; AR 1959, 10. Such classes continued until at least 1965 .

34 See for example Manitoba, AR 1954-55, Report, Superintendent of Schools, Winnipeg, 94 (by which time Winnipeg had five special classes in elementary English); ibid., 1957-58, 105 (that year there were four classes): "As in the past, younger children were placed directly in primary classes even though their English was limited, but the placement of older children was deferred until their English had been brought closer to their level of general achievement." The Alberta $A R 1950$ reported no special classes for "new Canadians" but by 1955 such classes existed in Edmonton, Lethbridge, and the Taber School Division: Alberta, AR 1955, 43. By 1952-53 Vancouver had 20 elementary school classes for new Canadians: British Columbia, AR 1952-53, p. P55. And although the numbers varied, these classes continued to be reported annually through to 1960-61.

35 Canadian School Journal (Aug.-Sept. 1956), 218-22, "Most Efficient Methods of Helping Non-English-Speaking Children with Reading."

36 See Sheffield, The SchoolXVIII, 8 (April 1930): 666; the author specifies that he is drawing on his experience with Doukhobor children.

37 Saskatchewan, $A R$ 1930, 13, and $A R$ 1929, 99.

38 Ernest Harvey Reid, "A Comparative Study of Secondary and Higher Educational Interests Among the Different Racial Groups of Manitoba," University of Manitoba, Faculty of Education, Alumni Association Research Bulletin, March 1939, 22.

39 Educational-Personal Problems in Alberta..., by a Sub-committee on Education and Vocational Training of the Alberta Post-War Reconstruction Committee, 1 Dec. 1943, mimeograph, p. 2. In 1943-44, those of non-British origin constituted 65 per cent; ibid. The figures were somewhat lower at the Calgary Normal School; see Robert M. Stamp, Becoming a Teacher in 20th Century Calgary: A History of the Calgary Normal School and the Faculty of Education, University of Calgary (Calgary: Temeron Books, 2004), 30, 38, 50.

40 Elizabeth McLachlan, With Unfailing Dedication: Rural Teachers in the West (Edmonton: NeWest Press, 2001), 177.

41 Elizabeth McLachlan, With Unshakeable Persistence: Rural Teachers of the Depression Era (Edmonton: NeWest Press, 1999), 88-89.

42 University of Alberta Archives, John C. Charyk Fonds, Box 10, (Mrs. H.) Ethel Workman, 15 March 1979. See also the comment by a teacher in a rural school on the prairies, "Some Teachers Obliged to Face Mutinous Parents," Maclean's Magazine 38 (15 Feb. 1924): 61: "I had to begin from the grass-roots, as none of my pupils could read or speak English."

43 R.S. Patterson, "Voices from the Past: The Personal and Professional Struggle of Rural School Teachers," in Schools in the West: Essays in Canadian Educational History, ed. Nancy M. Sheehan, J. Donald Wilson, and David C. Jones (Calgary: Detselig, 1986), 109.

44 Penelope Stephenson, “Mrs. Gibson Looked as if She was Ready For the End of Term': The Professional Trials and Tribulations of Rural Teachers in British Columbia's Okanagan Valley in the 1920s," in Children, Teachers and Schools in the History of British Columbia, ed. Jean Barman, Neil Sutherland, and J. Donald Wilson, 240-41. See also Thomas Fleming, The Principal's Office and Beyond, vol. 1 (Calgary: Detselig, 2010), 256-58; Thomas Fleming, ed., Schooling in British Columbia, 1849-2005: Voices from the Past (Mill Bay, BC: Bendall Books, 2010), 189; Helen Raptis, "Bending the bars of the identity cage: Amy Brown and the development of teacher identity in British Columbia," History of Education 39, 2 (2010): 211-13. Our thanks to an anonymous assessor for this latter reference and for an additional reference in note 60 . 
45 See comment in PAA, 79.334, Department of Education, Interprovincial Correspondence, Manitoba, Box 1, File 5, Registrar [Alberta Department of Education] to H.G. Mingay, Registrar, Manitoba Department of Education, 13 Jan. 1931.

46 Black, English for the Non-English, 93. Black documented this assertion through responses to his questionnaire. See 150-56.

47 Anderson, Education of the New Canadian, 231.

48 Alberta, AR 1923, 61.

49 McLachlan, Persistence, 8.

50 Manitoba, AR 1939-40, 54-55. Even then, teaching reading is not the same as teaching non-English children how to speak or understand the spoken word.

51 See Alberta Normal Schools Announcement 1921-22; Alberta Normal Schools Announcement 1931-32; Alberta Normal Schools Announcement 1940-41. These Announcements list, in greater or lesser detail, the courses offered in the regular program. Lists of courses can also be found in the Normal School Reports printed in the Alberta ARs; see for example 1921,$43 ; 1922,41 ; 1932,30 ; 1937,38 ; 1938,19$. See also PAA, Acc. 78.92, Box 3, item 2, Camrose Normal School, n.d. (between letters dated 16 Sept. and 30 Sept. 1932): list of teachers and subjects for session - there is no ESL or training for non-English teaching in this list; PAA, 78.92, Correspondence from the Normal Schools at Lethbridge..., G.F. Manning, Principal, to Mrs. Mabel McDonald, 7 Jan. 1943 (lists courses taken by her daughter - no distinct ESL course). In his detailed account of the history of the Calgary Normal School, Robert Stamp makes no reference at all to ESL as part of initial teacher training before 1970. See Stamp, Becoming a Teacher, passim.

52 We have examined the University of Alberta Faculty of Education calendars from the 1940s through 1968-69. No distinct ESL course is included as late as the calendar for 1960-61. However, by 1965-66 an optional "Program in Intercultural Education" had been introduced that included an arts course in linguistics and an ESL course offered by the faculty. That continued to be the case through the rest of the 1960s. See Calendar of the University of Alberta, Edmonton, Faculty of Education, 1965-66, 227 and 245; University of Alberta Calendar, 1968-69, Edmonton, 73.2, 73.3.4, 74.5.1.

53 See Alberta Normal Schools Announcement 1921-22, 15-16.

54 British Columbia, AR 1928-29, R58, and AR 1929-30, Q25; ATAMXIII, 9 (May 1933): 8. The course description for 1929 suggests this was for adults, not children. The British Columbia Department of Education, and university, summer courses are routinely advertised in the teachers' magazines, including the ATAM. For the lack of any ESL-type courses in British Columbia, see for example ATAMXII, 10 (June 1932): 16; XIV, 8 (April 1934): 19; XV, 9 (May 1935): 13; XVI, 9 (May 1936): 15; XX, 9 (May 1940): np [inside, front cover]. See also Helen Raptis, "Dealing with Diversity: Multicultural Education in British Columbia, 1872-1981" (PhD diss., University of Victoria, 2001), 50-51.

55 For the courses offered 1916-1921, see Fanny M. Davis, "The History of the Growth of the Faculty of Education within the University of Manitoba" (MEd thesis, University of Manitoba, 1957), 23; announcements in WSJXII, 5 (May 1917): 163; XIII, 2 (Feb. 1918): 49; XIV, 5 (May 1919): 161; XV, 5 (May 1920): 157-58; XVI, 5 (May 1921): 584; W.J. Sisler, Peaceful Invasion (Winnipeg: Ketchen Printing Co., 1944), 32-33. No ESL courses are listed in the journal in 1923 or 1924: see WSJXVIII, 2 (Feb. 1923): 451-52; ibid., XIX, 3 (March 1924): 895-96. For the Manitoba summer school courses in the calendars, see Manitoba Summer School Calendars, 1926 (which also gives enrolments for 1925) through 1942; after this date we have been unable to locate lists of course offerings.

56 Notices in WSJXXIII, 1 (Jan. 1928): 3, and XXIII, 4 (April 1928): 127; Manitoba, AR $1927-28,25$. 
57 Alberta, AR 1920, 34-36.

58 The ATAM advertised such courses in 1930 and 1931 but we have not found advertisements in any other years in this period: see ATAMX, 9 (May 1930): 8, and XI, 9 (May 1931): 29. Beginning in 1927 and 1928, the Alberta Department of Education, stimulated by support from the IODE, offered summer school training for those teaching in schools with large non-English populations. See ATAMVII, 12 (June 1927): 18, and advertisement, inside front cover; VIII, 7 (Feb. 1928): 15. Archival sources make it clear that teachers enrolled in these IODE-assisted programs were by the 1930s mainly upgrading their certificates by taking regular summer school courses. See for example PAA, 79.334, Box 9, File 72, IODE 1930-43, G.F. McNally to Mrs. M.B. Drummond, 24 April 1930 (re IODE scholarships for 1929 and 1930); ibid., List of IODE Scholarship Teachers [1931]; ibid., Director of Summer School, Edmonton, to Mrs. W.V. Hessey, 20 Sept. 1933; ibid., same to same, 27 June 1934. When in 1942 the Canadian military authorities wrote asking for help in improving the language skills of enlistees of "central European origin," the Alberta Department of Education replied that it had "no material available" for this purpose: PAA, 79.334, Box 15, File 171, Correspondence re educational programs in the Canadian Forces 1942, Andrew Moore, Deputy Chairman and Director, Canadian Legion War Services Inc., Educational Services, to G. Fred McNally, Deputy Minister, Education, Alberta, 19 March 1942, and ibid., T.A. McMaster, Deputy Director, for Andrew Moore, Director, to A.C. Newland, Supervisor of Schools, Department of Education, Edmonton, 14 April 1942.

59 The School 20, 9 (May 1932): 768-73.

60 For a summary of the courses and enrolments in the 1930s see Ontario, AR 1939, 134. For 1946-55 see Ontario, AR 1955, 44. For 1949-59 see Ontario, AR 1959, S-17. The ESL course was first offered in 1958 and every year after that to at least 1970. It should be noted that materials for English-language instruction increasingly became available from mid-century on, and sought after by public school teachers across North America, due for example to the efforts of Edith Lucas, an experienced teacher and principal who produced lessons and books while working for the British Columbia Department of Education. See Helen Raptis, "Pushing Physical, Racial, and Ethnic Boundaries: Edith Lucas and Public Education In British Columbia, 1903-1989," in One Step over the Line: Toward a History of Women in the North American Wests, ed. Elizabeth Jameson and Sheila McManus (Edmonton and Athabasca: University of Alberta Press and Athabasca University Press, 2008), 226-28.

61 Ashworth, Blessed with Bilingual Brains, 77. For Ashworth's career see Raptis, "A Tale of Two Women," 307-15.

62 The best detailed overview of developments across Canada in the 1960s and early 1970s is Mary Ashworth, Immigrant Children and Canadian Schools (Toronto: McClelland and Stewart, 1975), chaps. 2-6. See also, on British Columbia, Raptis, "Dealing with Diversity," 112-13.

63 Ashworth, Blessed with Bilingual Brains, 149.

64 Ashworth, Immigrant Children and Canadian Schools, 132. However, far more teachers with more than three years of experience had obtained special training, presumably through in-service or summer school courses.

65 Ashworth, Blessed with Bilingual Brains, 153. There is an excellent summary of the types of programs on offer by the 1980s along with a province-by-province description of programs available, in ibid., chap. 4.

66 Jim Cummins, "Heritage Language Teaching and the ESL Student: Fact and Friction," in Multicultural Education and Policy: ESL in the 1990s; A Tribute to Mary Ashworth, ed. John H. Esling (Toronto: OISE Press, 1989); this is a summary of a more extended review of research findings in Jim Cummins, Bilingualism and Minority-Language Children (Toronto: OISE Press, 1981). For the Toronto origins of experiments with 
bilingual ESL programs, see Loren Lind, The Learning Machine: A Hard Look at Toronto Schools (Toronto: Anansi, 1974), chap. 2, esp 44ff.; Maseman, "Multicultural Programs in Toronto Schools," passim. 